\title{
A STUDY ON ANEUPLOIDY IN HUMAN PERIPHERAL LEUKOCYTES AND BONE MARROW CELLS"
}

\author{
T. SUGAHARA, M. SAKURAI, M. KAWASAKI, AND Y. DOIDA
}

Department of Experimental Radiology, Faculty of Medicine, Kyoto University, Kyoto

Received November 28, 1966

It has been reported by Jacobs et al. (1963) and confirmed by Hamerton et al. (1965) that there was a gradual increase in aneuploidy, especially hypodiploidy, with age in human peripheral leukocytes and that the increase seems to be due mainly to loss of sex chromosomes. They have suggested that loss of any chromosome but a genetically inactive $\mathrm{X}$ or a $\mathrm{Y}$ leads to death of the cell due to chromosome imbalance, so that only hypodiploid cells in which these particular chromosomes are missing can survive. This may be true for embryonic cells because there have been no reports on cases of autosomal monosomy (Kerr and Rashad 1966). In irradiated persons, however, the increased incidences of aneuploid cells have been reported (Buckton et al.1962, Bender and Gooch 1962, Doida et al. 1965). Here, a wide distribution of missing chromosomes among various chromosome groups were found (Doida et al. 1965). The other example is seen in leukemic patients whose stem cell lines demonstrated autosomal monosomies (Sandberg et al. 1964, Fitzgerald et al. 1964). In the present study, an analysis of the pattern of lost chromosomes in hypodiploid cells was carried out in order to shed some light on the nature of aneuploidy in human cells in vivo.

Samples were taken from various persons, young and aged, normal and abnormal, and irradiated and nonirradiated. Preparation of slides followed the procedure of Moorhead et al. (1961) for peripheral leukocytes and that of Kiossoglou et al. (1964) for bone marrow cells. Karyotypes were prepared from cells with well-spread 45 chromosomes according to the Denver classification (44 chromosomes in case of $\mathrm{XO} / \mathrm{XY}$ mosaics). Among them only cells with loss of a single chromosome were selected for analysis and lost chromosomes were classified according to Patau's grouping (Patau 1961). The reason why the grouping method was adopted is to avoid the confusions due to uncertainties involved in identification of chromosomes in each group. Cells with additional chromosomes, either normal or abnormal, were excluded from analysis because of the possibility of translocation of parts of lost chromosomes to the additional ones. Data from various cases were pooled because it was the purpose of this preliminary report to demonstrate a general trend in the chromosome missing rather than to observe slight differences among various cases. The latter purpose will be pursued in future studies.

The results are summarized in Table 1. A total of 167 metaphase plates from 49 individuals were analysed. Expected values were calculated based on the relative number of chromosomes belonging to the group according to the Denver classification

1) Contribution No. 37 from the Department of Experimental Radiology, Faculty of Medicine, Kyoto University 
for peripheral blood cells. Although sex difference in the types of missing chromosomes was reported by Jacobs et al. (1963), we are not able to demonstrate sex-dependency in the present study. The number of bone marrow cells analysed is insufficient for statistical analysis but their pattern of missing chromosomes seems to be similar to that of peripheral leukocytes.

Ford (1964) suggested in the mouse that the missing of chromosomes is an artifact. However, we believe that most of the missing chromosomes are not likely to be an artifact because the incidence of missing chromosomes does not depend on the number of chromosome per group nor the size of chromosomes (Table 1). Here, the chromosomes in groups $\mathrm{A}, \mathrm{B}$ and $\mathrm{F}$ have shown abnormally low incidences of missing. No cells with missing chromosomes of group B, seven cells with missing chromosomes of group A and two cells with missing chromosomes of group F are observed in 170 metaphase plates studied. Similarly, the absence of the cells with missing chromosomes of groups $\mathrm{A}, \mathrm{B}$ and $\mathrm{F}$ are noted in the studies of bone marrow cells of acute leukemic patients (Sandberg et al. 1964, Fitzgerad et al. 1964, Kiossoglou et al. $1965 \mathrm{a}$ and b). Hypodiploid stem cell lines without gain of normal or abnormal chromosomes in the bone marrow of acute leukemia patients are summarized from references (Table 2). These chromosomes, three pairs of group A, two pairs of group B and two pairs of group F, may be regarded as the indispensables for survival of peripheral leukocytes, probably true for lymphocytes as well as bone marrow cells. However, it should be mentioned that there may be other chromosomes indispensable for the cells, but not demonstrable by the present method of rough grouping. Since most of the cells with missing chromosomes in group B and/or group $\mathrm{F}$ in acute leukemic patients (Sandberg et al. 1964) have abnormal chromosomes, the loss of chromosomes in the acute leukemic patients may have resulted from translocations involving these chromosomes.

Regarding chromosomes of other groups, a clonal cell line with missing a chromosome of group $\mathrm{E}$ was found in one case $(73)$ of atomic bomb survivors (Doida and Sugahara 1965). Although incidences of loss of chromosome in group $G$ in male and chromosome of group $\mathrm{C}$ in female were higher than chromosomes of other groups (Table 1), the incidence was not significantly different from the expected value, contrary to significant differences observed by Jacobs et al. (1963) and Hamerton et al. (1965). The discrepancy should be studied further but may stem from the fact that the subjects of the present investigation include many cancer patients, atomic bomb survivors, radiation personnel and so on, while those in others (Jacobs et al. 1963, Hamerton et al. 1965) deal with normal persons.

It may be concluded that chromosome loss in cells with 45 normal chromosomes are mainly the result of abnormality in the preceeding cell division or ancestral cell lines and only rarely a consequences from technical failure during the preparation of slides. There is good reason to assume that somatic cells require a fraction of the total genome to direct processes of differentiated cells. The results may suggest that all autosomes are indispensable for embryological development but only certain ones including chromosomes of group A, B and F may be essential for blood forming cells. Similar studies should be extended to other type of cells such as skin and tumor cells in order to shed light on the biological implications of human chromosomes in each cell. 
Table 1. Distribution of chromosome missing in hypodiploid cells with normal chromosome complements missing one chromosome

\begin{tabular}{|c|c|c|c|c|c|c|c|c|c|}
\hline Sex & No. of cases & A & B & C & $\begin{array}{l}\text { Chromos } \\
\text { D }\end{array}$ & $\underset{E}{\stackrel{s}{s} \text { me }}$ & $\underset{\mathrm{F}}{\operatorname{group}}$ & G & Total \\
\hline \multicolumn{10}{|l|}{ Peripheral blood cells } \\
\hline Male & $\begin{array}{l}24 \text { observed }_{\text {expected }}^{\mathrm{a}} \\
\text { ent }\end{array}$ & $\begin{array}{l}3 \\
5.9\end{array}$ & $\begin{array}{l}0 \\
3.9\end{array}$ & $\begin{array}{l}14 \\
14.7\end{array}$ & $\begin{array}{l}6 \\
5.9\end{array}$ & $\begin{array}{c}12 \\
5.9\end{array}$ & $\begin{array}{l}1 \\
3.9\end{array}$ & $\begin{array}{l}9 \\
4.9\end{array}$ & $\begin{array}{l}45 \\
45.1\end{array}$ \\
\hline Female & $\begin{array}{l}27 \text { observed }^{\text {expected }} \\
\text { a }\end{array}$ & $\begin{array}{l}2 \\
11.3\end{array}$ & $\begin{array}{l}0 \\
7.7\end{array}$ & $\begin{array}{l}37 \\
30.0\end{array}$ & $\begin{array}{l}10 \\
11.3\end{array}$ & $\begin{array}{l}13 \\
11.3\end{array}$ & $\begin{array}{l}1 \\
7.7\end{array}$ & $\begin{array}{l}24 \\
7.7\end{array}$ & $\begin{array}{l}87 \\
87\end{array}$ \\
\hline \multirow[t]{2}{*}{ Total } & $\begin{array}{l}51 \text { observed }^{\text {expected }} \\
\text { a }\end{array}$ & $\begin{array}{c}5 \\
17.2\end{array}$ & $\begin{array}{c}0 \\
11.6\end{array}$ & $\begin{array}{l}51 \\
44.7\end{array}$ & $\begin{array}{l}16 \\
17.2\end{array}$ & $\begin{array}{l}25 \\
17.2\end{array}$ & $\begin{array}{c}2 \\
11.6\end{array}$ & $\begin{array}{l}33 \\
12.6\end{array}$ & $\begin{array}{l}132 \\
132.1\end{array}$ \\
\hline & $\mathrm{X}^{2}$ & $8.65^{*}$ & $11.60^{* *}$ & 0.89 & $\begin{array}{ll}9 & 0.08\end{array}$ & 3.54 & $7.94 *$ & $33.03 * *$ & 65.73 \\
\hline \multicolumn{10}{|l|}{ Bone marrow cells } \\
\hline Male & 3 observed & 1 & 0 & 9 & 0 & 3 & 0 & 3 & 16 \\
\hline Female & 3 observed & 0 & 0 & 3 & 0 & 1 & 0 & 3 & 7 \\
\hline $\begin{array}{r}\text { XO/XY mosaic } \\
(X O \text { cells) }\end{array}$ & 2 observed & 1 & 0 & 4 & 3 & 2 & 0 & 2 & 12 \\
\hline Total & 8 observed & 2 & 0 & 16 & 3 & 6 & 0 & 8 & 35 \\
\hline
\end{tabular}

a Expected value was calculated assuming random distribution of missing chromosomes.

* Significantly different from expected value at 1 per cent level.

** Significantly differ

Table 2. Hypodiploid stem cell lines without gain of normal or abnormal chromosomes in the bone marrow of acute leukemia patients

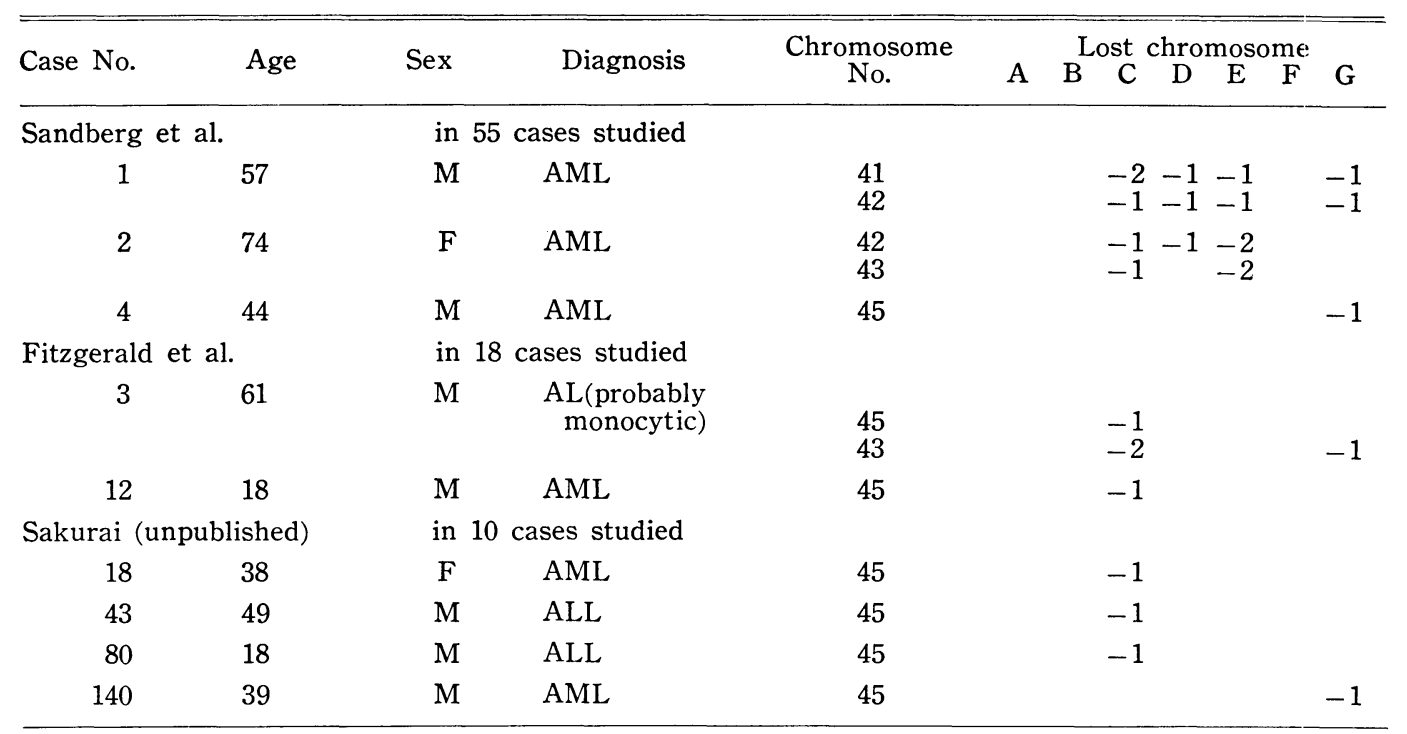

\section{ABSTRACT}

The distribution of lost chromosomes in Patau's grouping was studied in cells with 45 normal chromosome complements. A total of 132 metaphase plates were karyotyped from cultured peripheral leukocytes and 35 from bone marrow cells. The pattern of 
missing chromosomes was found to be significantly different from expectation based on the number of chromosomes per group. Unusually low incidences of missing chromosomes of groups A, B and $\mathrm{F}$ were discovered.

\section{AKNOWLEDGEMENT}

The work was supported in part by the grants from Suntory Ltd. and Mitaya Mfg. Co. Ltd. Expert technical assistance by Miss A. Onohara is greatly appreciated. The authors wish to thank Drs. L. H. Hempelmann and S. Okada, Department of Radiology, University of Rochester, Rochester, N.Y. for their valuable suggestions in completing this manuscript.

\section{LITERATURE CITED}

Bender, M. A., and P. C. Gooch, 1962 Persistent chromosome aberrations in irradiated human subjects. Radiat. Res. 16: 44-53.

Bucktion, K. K., P. A. Jacobs, W. M. Court Brown, and R. Doll, 1962 A study of the chromosome damage persisting after X-ray therapy for ankylosing spondylitis. Lancet ii: 676-682.

Doida, Y., T. Sugahara, and M. Horikawa, 1965 Studies on some radiation-induced chromosome aberrations in man. Radiat. Res. 26: 69-83.

Doida, Y., and T. Sugahara, 1965 Comparative studies on chromosome aberrations in man induced by irradiations under various conditions. Excerpta Med. Intern. Congr. Ser., No. 89: 110.

Fitzgerald, P. H., A. Adams, and F. W. Gunz, 1964 Chromosome studies in adult acute leukemia. J. Natl. Cancer Inst. 32: 395-417.

Ford, C. E., 1964 Selection pressure in mammalian cell populations. In "Cytogenetics of Cells in Culture" (R. J. C. Harris, ed.) pp. 27-45, Academic Press, New York.

Hamerton, J. L., A. I. Taylor, R. Angell, and V. M. McGuire, 1965 Chromosome abnormalities and distribution of chromosome counts according to age and sex among the population of Trista da Cunha. Nature 206: 1232-1234.

Jacobs, P. A., M. Brunton, W. M. Court Brown, R. Doll, and H. Goldstein, 1963 Changes of human chromosome count distribution with age: Evidence for a sex difference. Nature 197: 1080-1081.

Kerr, M., and M. N. Rashad, 1966 Chromosome studies on spontaneous abortions. Am. J. Obstet. Gynecol. 94: 322-339.

Kiosscglou, K. A., W. J. Mitus, and W. Dameshek, 1964 A direct method for chromosome studies of human bone marrow. Am. J. Clin. Pathol. 41: 183-187.

Kiossoglou, K. A., W. J. Mitus, and W. Dameshek, 1965a Chromosome aberrations in pernicious anemia: Study of three cases before and after therapy. Blood 25: 662-681.

Kiossoglou, K. A., W. J. Mitus, and W. Dameshek, 1965b Two Ph chromosomes in acute granulocytic leukemia. A study of two cases. Lancet ii: 665-668.

Moorhead, P. S., P. C. Nowell, W. M. Mellman, D. H. Batlips, and D. A. Hungerford, 1961 Chromosome preparations of leukocytes cultured from human peripheral blood. Exptl. Cell Res. 20: 613-616.

Patau, K., 1961 Chromosome identification and the Denver report. Lancet i: 933-934.

Sandberg, A. A., T. Ishihara, Y. Kikuchi, and L. H. Crosswhite, 1964 Chromosome differences among the acute leukemias. Ann. N. Y. Acad. Sci. 113: 663-716. 